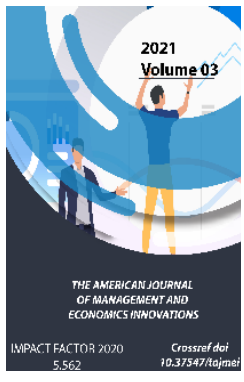

Journal Website: http://theamericanjour nals.com/index.php/taj mei

Copyright: Original content from this work may be used under the terms of the creative commons attributes 4.0 licence.

\section{Basic Principles Of Reform And Connection In The Field Of Higher And Vocational Education In Uzbekistan}

\author{
Rakhmonova Aziza Tolibovna \\ Master Of Samarkand Institute Of Economics And Service, Uzbekistan
}

Sh.A. Musayeva

Samarkand Institute Of Economics And Service, Uzbekistan

D.H. Kholmamatov

Samarkand Institute Of Economics And Service, Uzbekistan

\title{
ABSTRACT
}

In recent years, specific measures have been taken to innovate the economic and social spheres of the republic, to provide comprehensive support and increase the efficiency of science and research. The article discusses the introduction of new and advanced pedagogical technologies in the development of the education system of the Republic of Uzbekistan and the importance of several important factors in the effective organization of this process and future prospects.

\section{KEYWORDS}

International experience, credit-module system, modern technology, advanced pedagogical technology, information technology, digital technology.

\section{INTRODUCTION}

Today, radical improvement of education has become a requirement of the times. Based on this requirement, laws are being enacted to regulate relations in the field of education. In particular, the Law of the Republic of Uzbekistan "On Education" was adopted on September 23, 2020, the purpose of which is to regulate relations in the field of education.In accordance with this Law, the basic principles in the field of education, the system, types, and forms of education are clearly defined, the rules of distance education set out in the curriculum and training programs provide students with the necessary knowledge, skills, and information, and communication. technologies and the Internet using the global information network. 
The law also provides for the establishment of state higher education, secondary special, vocational education institutions, and their affiliates, as well as state-owned higher, secondary special, vocational education institutions and their branches by presidential or government decrees. The establishment of non-governmental educational institutions will be carried out by their founders. Licenses for non-governmental educational institutions will be issued by the State Inspectorate for Quality Control in Education.

The law sets out the rules for dual education, which are aimed at providing students with the necessary knowledge, skills, and abilities, the theoretical part of which is based on the educational institution, and the practical part is based on the student's workplace. In addition, the law introduces provisions on inclusive education, which aims to ensure equal access to education for all students in educational institutions, taking into account the specific educational needs and the diversity of individual opportunities. Provides inclusive education in educational institutions for children (individuals) with physical, mental, sensory (sensory), or mental disabilities.

This law differs radically from the Law on Education of August 29, 1997, which is broad and specific in its regulation of relations in the field of education in accordance with the requirements of international standards.

Of course, some of the reforms in the education system are in the higher education system.

In particular, setting priorities for systemic reform of higher education in the Republic of Uzbekistan, raising the process of training highly qualified independent thinking to a qualitatively new level, modernization of higher education, development of social sphere and economy based on advanced educational technologies The Concept of Development of the Higher Education System of the Republic of Uzbekistan until 2030, approved by the Decree of the President of the Republic of Uzbekistan No. PF-5847 dated October 8, 2019, serves as a prelude to new reforms in this area.

In recent years, specific measures have been taken to innovate the economic and social spheres of the republic, to provide comprehensive support and increase the efficiency of science and research.

A strategic program aimed at including the country in the list of 50 leading countries in the global ranking of innovations was approved, new mechanisms for financing research projects were introduced, additional conditions were created for financial incentives for highly qualified personnel in science.

However, the large-scale reforms underway at the current stage of the country's development are aimed at improving the mechanisms of public administration in science and innovation, increasing transparency in the formation of state programs for scientific activities and the introduction of scientific achievements and innovative technologies in industries and regions. indicates the need to accelerate.

It should be noted that modern pedagogical technologies can be combined with technological processes in other areas, enrich their content and open up new opportunities 
for an effective approach to the educational process. An example of this is the combination of information technology, digital technology and modern pedagogical technologies. To clarify our point, the combination of information technology, digital technology and modern pedagogical technologies can be called a dialogue between the studentcomputer-wireless networks (Internet) teacher>. They are an integral part of the new era of pedagogical technology, which began to be used in the educational process as an advanced modern type of technical means. In the context of the prevailing pandemic in our country, a new, modern form of teaching and learning has been introduced to the general public, that is, we have managed to get distance learning, which we call "Studentcomputer-wireless networks. We cannot imagine without the combination of (internet) -edagogues. Digital technology has played an important role in the organization of such classes. We have, of course, accomplished the goal of the lesson in these conditions with wireless networks, internet networks and of course computer technology. This is the most modern approach to education today, and it is no exaggeration to say that we have been able to take a new direction in education. In addition to distance learning, there is a lot of information on the organization of lessons through software applications for the combination of digital technology information technology - modern pedagogical technology. Examples include the online journal program, video conferencing, video puzzle learning technology, and virtual booths that are currently being introduced in other educational institutions.

When we talk about the modernization and effectiveness of education, another important factor is, of course, the adoption of international experience. It is no exaggeration to say that the introduction of international and foreign experience, that is, the best practices of countries that have their own direction and method of education, is one of the goals of public policy in our country today. At the same time, the approval of the "Concept of Development of the People's System of the Republic of Uzbekistan until $2030 "$ is a clear proof of this.

This concept defines the priorities of the systemic reform of the system of general secondary and out-of-school education in the Republic of Uzbekistan, raising the spiritual, moral and intellectual development of the younger generation to a qualitatively new level. In order to introduce innovative forms and methods of education in the world of education, the Republic of Uzbekistan will be ranked in the top 30 in the world by PISA (The Program for International Student Assessment) by 2030. Another priority is to join the ranks of developed countries, as well as:

- Qualitative updating of the content of continuing education, as well as training, retraining and advanced training of professionals

- Improving teaching methods, gradual implementation of the principles of individualization in the educational process,

- The implementation of tasks such as the introduction of modern information and communication technologies and innovative projects in the field of public education has been set and the first steps are being taken. 
As part of the introduction of another international experience, the experience of the Korean state was introduced, which is a well-known credit-module system. Due to the fact that this credit module experience has yielded good results in Korea, this international and advanced experience has been established in some of our universities. And with the introduction of the creditmodule system of education in educational institutions, we can see that the quality of education has improved. Indeed, such tried and tested international practices will continue to be adopted and I hope that they will be effective in modernizing our education system.

In conclusion, reforms in the field of education today are no less relevant and practical than reforms in other areas. It is time to continue the reforms in this area on a larger scale.

\section{REFERENCES}

1. Decree of the President of the Republic of Uzbekistan dated April 1, 2021 No. PF-6198 "On improving the system of public administration for the development of scientific and innovative activities".

2. Decree of the President of the Republic of Uzbekistan "On additional measures to improve the system of public education" No PF-5538. 05.09.2018.

3. Sobirovna, T. R. (2021). Issues of further improvement of water cadastre legislation of Uzbekistan. ACADEMICIA: An International Multidisciplinary Research Journal, 11(4), 1241-1253.
4. Тошбоева, Р. С. (2020). ПРЕДОСТАВЛЕНИЕ КАДАСТРОВОЙ ИНФОРМАЦИИ О ПРИРОДНЫХ РЕСУРСАХ: ПРОБЛЕМЫ И ПУТИ ИХ РЕШЕНИЯ. ЖУРНАЛ ПРАВОВЫХ ИССЛЕДОВАНИЙ, 5(3).

5. TOSHBOEVA, R. (2021). РЕФОРМИРОВАНИЕ ПРИРОДНОРЕСУРСОВОЙ КАДАСТРОВОЙ СИСТЕМЫ УЗБЕКИСТАНА: СОВРЕМЕННЫЕ ТЕНДЕНЦИИ И ПУТИ ИХ ПРАВОВОЙ РЕГЛАМЕНТАЦИИ. ЮРИСТ АХБОРОТНОМАСИ, 2(1), 74-85.

6. Rakhmatov, D., \& Nomozova, E. (2020). The use of multimedia technologies in the educational system and teaching methodology: problems and prospects. International Journal of Discourse on Innovation, Integration and Education, 1(2), 28-32.

7. M.F. Hakimova, N.X. Xo'jayev, D.Q. Axmedov. Zamonaviy pedagogik texnologiyalar. O'quv qo'llanma.T.:TDIU nashr., 2006y, 52-53-betlar.

8. N.Muslimov, Z.Raximov, X.Qodirov "Ta'lim texnologiyalari" darslik. Toshkent-2017. 11-bet.

9. Рахматов Д.Р. (2020). Современные информационные технологии в системе образования: проблемы и перспективы. Актуальные проблемы инновационного сотрудничества в повышении качества высшего образования, Международная научная онлайн конференция 27 мая 2020 года, Навои, 183-186. 